\title{
Caseinomacropeptide index in UHT whole milk stored under different conditions of temperature and time
}

[Efeito das condições de armazenamento no índice de caseinomacropeptídeo de amostras de leite integral ultra alta temperatura (UAT)]

\author{
C.N.B.C. Villanoeva ${ }^{1}$, E.H.P. Andrade ${ }^{1}$, J.C. Baffa Junior ${ }^{2}$, M.R. Souza ${ }^{3}$,
} M.M.O.P. Cerqueira, , L.M. Fonseca ${ }^{3}$, C.F.A.M. Penna ${ }^{3}$, M.O. Leite ${ }^{3}$

\footnotetext{
${ }^{1}$ Aluna de pós-graduação - Escola de Veterinária - Universidade Federal de Minas Gerais - Belo Horizonte, MG

${ }^{2}$ Escola de Engenharia de Alimentos - Universidade Federal de Viçosa - Viçosa, MG

${ }^{3}$ Escola de Veterinária - Universidade Federal de Minas Gerais - Belo Horizonte, MG
}

\begin{abstract}
Caseinomacropeptide (CMP) index is a method used to detect adulteration of milk by addition of cheese whey, since CMP is a glycopeptide characteristic produced during cheesemaking, and soluble in the whey phase. The objective of this work was to evaluate the caseinomacropeptide index of UHT milk stored under different temperatures. Six batches of recently processed UHT milk were collected and stored under three temperatures $\left(21^{\circ} \mathrm{C}, 6^{\circ} \mathrm{C}\right.$, and $\left.-12^{\circ} \mathrm{C}\right)$ and analyzed by HPLC in the day of the milk collection (day 0 ) and at 30, 60, 90, and 120 days of storage. The experiment was run as a randomized block design with a $3 \times 5$ factorial arrangement, and the Student-Newman-Keuls (SNK) method was used as the posthoc test $(\mathrm{p}=0.05)$. There was a progressive increase of the CMP index during the storage period of 120 days, and this indicates the possibility of false positive results if the CMP index is used as an adulteration test for long term stored UHT milk. The validity of the CMP index as an adulteration indicator is only possible soon after packaging, and sample freezing is the only alternative when immediate analysis is not possible. The method was found to be precise, with robust CV of $1.9 \%$ even with high CMP levels.
\end{abstract}

Keywords: UHT whole milk, caseinomacropeptide, HPLC

\section{RESUMO}

O objetivo deste trabalho foi avaliar a influência da temperatura e do tempo de armazenamento de amostras de leite UAT, em relação ao índice de caseinomacropeptídeo, por cromatografia líquida de alta eficiência, e a precisão do método de detecção. Seis lotes foram coletados e armazenados em três temperaturas $\left(21^{\circ} \mathrm{C}, 6^{\circ} \mathrm{C} e-12^{\circ} \mathrm{C} \pm 1{ }^{\circ} \mathrm{C}\right)$ e analisadas durante o armazenamento nos dias $0,30,60,90 \mathrm{e}$ 120 dias. Utilizou-se o delineamento em blocos casualizados com os tratamentos em arranjo fatorial $3 \times 5$ e os resultados foram comparados por meio do teste Student-Newman-Keuls (SNK) a 5\% de significância. Houve aumento progressivo do índice de CMP por CLAE durante os 120 dias; portanto, um produto conforme pode se tornar não conforme sem que ocorra adulteração. A detecção de fraude por adição de soro lácteo em leite UAT pode ser detectada somente após o envase. Caso não seja possivel a análise imediata, recomenda-se que as amostras sejam congeladas. $O$ método é muito preciso ( $C V=1,9 \%)$ e indiferente aos níveis de CMP encontrados nas amostras.

Palavras-chave: leite UAT, caseinomacropeptideo, CLAE

Recebido em 29 de outubro de 2012

Aceito em 20 de agosto de 2013

*Autor para correspondência (corresponding author)

E-mail: monicaoliveiraleite@gmail.com 


\section{INTRODUCTION}

Ultra High Temperature (UHT) milk is processed by homogenization and heating at a temperature range of $130^{\circ} \mathrm{C}$ to $150^{\circ} \mathrm{C}$ during two to four seconds, followed by cooling to $32^{\circ} \mathrm{C}$, and aseptic packaging (Brazil, 1997). There is a high consumption in Brazil, mainly due to its ease of handling and storage, which can be at room temperature. UHT milk physical-chemical characteristics and sensorial properties are influenced by several reactions that may occur during and after heating. Among other changes, these reactions can result in cooked or stale flavors, protein gelation, and proteolysis. The proteolysis may occur due to the action of endogenous enzymes such as plasmin or leukocyte proteases present in the milk, enzymes that are added during the cheese making process and / or psychrotrophic microorganisms, which produce extracellular proteases that are heat resistant and thus contribute significantly to protein degradation.

During cheesemaking, the proteolysis of $\kappa$-caseín by chymosin will result in the bond cleavage between amino acids phenylalanine (position 105) and methionine (position 106). The resultant products are the insoluble para- $\kappa$-caseín (105 amino acids) which will be retained in the cheese and the soluble glycomacropeptide called caseinomacropeptide (CMP) (polypeptide amino acids 106-169) which will be found in the whey.

CMP detection is one of the methods used to detect fraudulent addition of cheese whey to the milk, although the CMP index may indicate false positive results when enzymes produced by psychrotrophic microorganisms cleavage the $\kappa$ caseín, resulting in polypeptides with size close to the CMP (Fukuda, 2003), it still remains a robust and trustworthy method to screen good quality milk.

Since one of the big challenges for milk inspection is to avoid adulteration of UHT milk, particularly by the addition of cheese whey, knowing the conditions that affect CMP levels is an important issue. In Brazil, the CMP Index method is ruled by the Federal Agriculture Ministry (Ministério da Agricultura, Pecuária e Abastecimento, MAPA) through Instrução Normativa $n^{\circ}$ 68/2006 (Brasil, 2006), and Instrução Normativa nº $7 / 2010$ (Brasil, 2010).
To accomplish the sampling needed for the official CMP Index method, representative UHT samples from each batch are kept under freezing conditions in the industry until official inspectors collect randomized samples from these frozen UHT milk boxes, during unforeseen visits, for HPLC analysis (Lasmar et al., 2011). The storage period can last weeks to months and this might affect CMP levels (Fukuda, 2003), so more research is needed to assure the robustness of this method.

The present work had the objectives of evaluating the temperature and storage time on the CMP index of UHT milk, and the robustness of the HPLC method.

\section{MATERIAL AND METHODS}

Six samples from different batches of UHT whole milk were collected in a dairy industry located in Belo Horizonte, Minas Gerais, Brazil. The samples were transported to the Chromatograph Laboratory of the School of Veterinary Medicine, Universidade Federal de Minas Gerais (UFMG), were they were stored under different conditions, i.e., $21^{\circ} \mathrm{C}, 6^{\circ} \mathrm{C}$, and $12^{\circ} \mathrm{C}$, and analyzed on the sampling day, and after 30, 60, 90, and 120 days of storage. Analyses included CMP index (Brazil, 2006), titratable acidity (Brazil, 2006), and pH (Brazil, 2006).

Additional analyses, including aerobic mesophilic and psychrotrophic microorganism counting were done in the Microbiology Laboratory of the School of Veterinary Medicine (UFMG), following official methods (Brazil, 2003).

For HPLC analysis of CMP a standard calibration curve was prepared using seven levels of CMP (Sigma) concentration: 0, 15, 30, 45, 60, 75 , and $90 \mathrm{mg} \mathrm{L} \mathrm{L}^{-1}$. An amount of $5 \mathrm{~mL}$ of trichloroacetic acid (24\%) was slowly added to $10 \mathrm{~mL}$ of each standard solution, left to rest for 60 minutes at room temperature, followed by filtration in qualitative paper, discarding the first drops (Brazil, 2006).

Approximately $20 \mu \mathrm{L}$ of each filtered solution was injected in the gas chromatograph (GC) equipment (Shimadzu CLASS VP 6.1) with a Zorbax GF 250 column (Agilent), with a flow of 
$1.5 \mathrm{~mL}$ min-1 (isocratic pumping with a of $\mathrm{pH} 6.0$ phosphate buffer solution) and UV detector set at 205nm. To establish the standard curve, CMP levels were plotted against signal intensity and regression values were accepted only with $R \geq 0.95$. Standard curves were prepared for each day of analysis. CMP index was quantified by peak height analysis compared to the standards peak height and retention time (Brazil, 2006). The final equation was $\mathrm{y}=\mathrm{ax}+\mathrm{b}$, where $\mathrm{x}=$ CMP index $\left(\mathrm{mg} \mathrm{L}^{-1}\right) ; \mathrm{y}=$ peak height; $\mathrm{a}=$ slope; and $b=y$ axis intercept. Thus, mathematically: $\mathrm{CMP}=($ Peak height $-\mathrm{b}) / \mathrm{a}$

The design was a factorial $3 \times 5$ randomized block experiment, with three temperatures $\left(-12^{\circ} \mathrm{C}, 6^{\circ} \mathrm{C}\right.$, and $\left.21^{\circ} \mathrm{C}\right)$, and five storage times $(0,30,60,90$, and 120 days) with six blocks in six batches of milk. Student-Newman-Keuls (SNK) was used for post-hoc comparison $(\mathrm{p}=0.05)$. Parametric variables, with normal distribution, were evaluated by the Pearson correlation, while non-parametric variables were transformed and evaluated by the Spearman correlation (Sampaio, 2007). Analysis of variance was done with SISVAR software (Ferreira, 2008), and descriptive analysis with SAEG (Sistema..., 2007)

\section{RESULTS AND DISCUSSION}

Average peak heights for the chromatograms of the milk stored under three temperatures and analyzed monthly are shown in Table 1. The effect of storage time temperature is shown in Figure 1.

Table 1. Chromatograms peak height values for CMP of UHT milk stored under $21^{\circ} \mathrm{C}, 6^{\circ} \mathrm{C}$ and $-12^{\circ} \mathrm{C}$ during 120 days $(n=6)$

\begin{tabular}{cccccc}
\hline Temperature & \multicolumn{5}{c}{ Time (Days) } \\
\cline { 2 - 6 }$\left({ }^{\circ} \mathrm{C}\right)$ & 0 & 30 & 60 & 90 & 120 \\
\hline 21 & $13,446 \mathrm{aA}$ & $35,470 \mathrm{aB}$ & $66,784 \mathrm{aC}$ & $76,997 \mathrm{aC}$ & $78,073 \mathrm{aC}$ \\
$6^{\circ} \mathrm{C}$ & $13,446 \mathrm{aA}$ & $19,851 \mathrm{bB}$ & $23,852 \mathrm{bB}$ & $21,867 \mathrm{bB}$ & $23,450 \mathrm{bB}$ \\
$-12^{\circ} \mathrm{C}$ & $13,446 \mathrm{aAB}$ & $15,664 \mathrm{bAB}$ & $16,718 \mathrm{cB}$ & $11,983 \mathrm{cAB}$ & $11,037 \mathrm{cA}$ \\
\hline
\end{tabular}

Different lower case letters in columns, or different capital letters in lines indicate statistical difference by the SNK test $(\mathrm{P}<0.05)$.

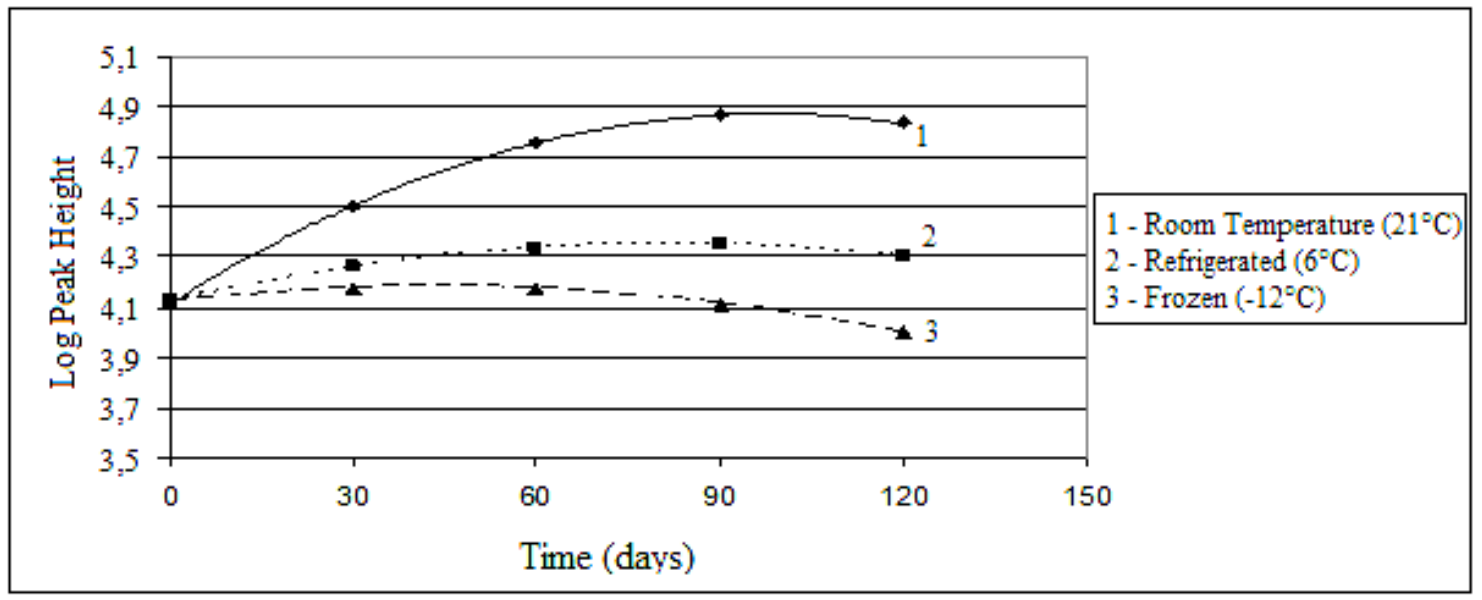

Figure 1 . The effect of UHT milk storage time $(0,30,60,90$, and 120 days $)$ and temperature $\left(21^{\circ} \mathrm{C}, 6^{\circ} \mathrm{C}\right.$, and $-12^{\circ} \mathrm{C}$ ) on CMP levels estimated by chromatogram peak heights $(\log )$.

The regression curves and determination coefficients related to Figure 1 are shown below:

- Room temperature $\left(21^{\circ} \mathrm{C}\right) \mathrm{y}=-4.999841 \mathrm{t}^{2}+1169.248 \mathrm{t}+10,998.069 \mathrm{R}^{2}=0.9956$

- Refrigerated $\left(6^{\circ} \mathrm{C}\right) \mathrm{y}=-1.232513 \mathrm{t}^{2}+221.645 \mathrm{t}+13,859.893 \mathrm{R}^{2}=0.9120$

- Frozen $\left(-12^{\circ} \mathrm{C}\right) \mathrm{y}=-0.961759 \mathrm{t}^{2}+87.078 \mathrm{t}+13,738.367 \mathrm{R}^{2}=0.7892$ 
After 30 days the CMP peak height of the milk stored at $21^{\circ} \mathrm{C}$ was higher than milk stored at $6^{\circ} \mathrm{C}$ and $-12^{\circ} \mathrm{C}$. After 60 days, significant difference was observed between the three storage temperatures, with higher peak heights observed with increasing storage temperatures.

According to the results of samples stored at room temperature, the increase in time was correlated to increasing CMP levels in milk. Similar findings were reported by Fukuda (2003) who correlated increasing CMP levels with proteolysis occurring during storage time of UHT milk.

Milk kept at $-12^{\circ} \mathrm{C}$ rendered a decreasing amount of proteolysis, when compared to the other storage temperatures. In order to minimize this effect, Fukuda (2003) proposed CMP quantification immediately after UHT milk production, without freezing the samples for later analysis. However, she worked with UHT samples stored at a temperature range of $-14^{\circ} \mathrm{C}$ to $-18^{\circ} \mathrm{C}$, and found peak heights of 8,$800 ; 7,304$; and 7,265 for recently produced milk and milk after $24 \mathrm{~h}$ and one month storage, respectively. These slightly decreasing levels over time have no practical implications for CMP index as an adulteration indicator.

Friedrich et al. (2010) evaluated CMP levels of UHT milk stored for up to 50 days at $21^{\circ} \mathrm{C}$, and reported an increase of the CMP index during storage, indicating increasing proteolysis. Usually this proteolysis is the result of endogenous enzymes, such as plasmin, or microbial enzymes, mainly produced by psychrotrophic microorganisms. The activity of microbial extracellular enzymes has a great impact on protein hydrolysis, and according to Fox (1992), their heat denaturation would only be possible at treatments as high as $142^{\circ} \mathrm{C}$ during 18 seconds or $120^{\circ} \mathrm{C}$ during 15 minutes. These treatments would negatively impact sensorial and physical chemical characteristics of UHT milk.

Although these microbial enzymes do not cleavage specific bonds, the resulting polypeptides may be the same size of the CMP, or close in size, when hydrolysis is in the bond between metionine (position 106) and alanine (position 107). This last polypeptide is called pseudo-CMP, and it is not differentiated from CMP by using only HPLC (Magalhães, 2008).

Derivative calculation for the linear regression curves showed that samples with maximum peak heights for the three storage temperatures were found at 116 days $\left(21^{\circ} \mathrm{C}\right), 89$ days $\left(6^{\circ} \mathrm{C}\right)$, and 45 days $\left(-12^{\circ} \mathrm{C}\right)$. Changes in peak heights, compared to the initial conditions, were evaluated according to the maximum height for each storage temperature (Table 2).

Table 2. Variation (\%) of the chromatogram CMP peak height according to the storage temperature and maximum peak height $(\mathrm{n}=6)$

\begin{tabular}{ccccccc}
\hline & \multicolumn{7}{c}{ Temperature $\left({ }^{\circ} \mathrm{C}\right)$} \\
\cline { 2 - 7 } Time (Days) & \multicolumn{2}{c}{$21^{\circ} \mathrm{C}$} & \multicolumn{2}{c}{$6{ }^{\circ} \mathrm{C}$} & \multicolumn{2}{c}{$-12^{\circ} \mathrm{C}$} \\
\cline { 2 - 7 } & Peak height & $\begin{array}{c}\text { Variation } \\
(\%)\end{array}$ & Peak height & $\begin{array}{c}\text { Variation } \\
(\%)\end{array}$ & $\begin{array}{c}\text { Peak height } \\
\text { Variation } \\
(\%)\end{array}$ \\
\hline 0 & 13,446 & 0 & 13,446 & 0 & 13,446 & 0 \\
45 & 53,490 & 297 & 21,338 & 59 & 15,709 & 17 \\
89 & 75,457 & 461 & 23,824 & 77 & 13,870 & 3 \\
116 & 79,353 & 490 & 22,986 & 71 & 10,898 & -19 \\
\hline
\end{tabular}

Samples stored at $-12^{\circ} \mathrm{C}$ had less change in CMP levels (Table 1 and Figure 1), confirming that, if storage is necessary, freezing the samples of UHT milk for a later analysis is the best option especially in countries with large territories, such as Brazil, where the shipment of samples for official laboratory network is difficult, and where there are not always enough laboratories to meet the demand.

Depending on the freezing temperatures, proteolysis might continue, since hydrolytic enzymes must be immobilized to decrease reactions to the lowest possible level. For 
maximum enzyme immobilization, it is necessary to reach temperatures as low as $-30^{\circ} \mathrm{C}$ at a fast rate for milk freezing and storage. This is not a practical situation in commercial freezers.

Samples stored at $6^{\circ} \mathrm{C}$ and $-12^{\circ} \mathrm{C}$ did not present live aerobic mesophilic microorganisms up to 120 days, showing conformity to the Brazilian legal requirements, which establishes a maximum of 100 colony forming units (CFU) $\mathrm{mL}^{-1}$ (Brazil, 1996). However, eight samples $(8.9 \%)$ stored at $21^{\circ} \mathrm{C}$ had microbial counting above these limits, reaching up to $10^{3} \mathrm{CFU} \mathrm{mL}^{-1}$.

Psychrotrophic microorganism countings were below 1 CFU $\mathrm{mL}-1$ for all samples in all experimental conditions. However, most psychrotrophic proteinases are extremely thermostable and can withstand the heat treatments with ultra-high temperature (UHT) (Cromie, 1992).

Titratable acidity results presented significant interaction $(p<0.05)$ between the temperature variables and during storage. Thus, using SNK, temperature variables were evaluated for each time, and afterwards, through linear regression, storage time variables were evaluated for each temperature.

Titratable acidity for the UHT milk samples stored under three temperatures for a four month period was evaluated at 30 day intervals (Table $3)$. The effect of storage time on the titratable acidity (expressed as $\mathrm{g}$ lactic acid $\mathrm{x} 100 \mathrm{~mL}-1$ ) is shown in Figure 2.

Table 3. Titratable acidity (expressed as g lactic acid in $100 \mathrm{~mL}^{-1}$ ) of UHT milk samples after storage at $21^{\circ} \mathrm{C}, 6^{\circ} \mathrm{C}$, and $-12^{\circ} \mathrm{C}$ during 120 days (n=6)

\begin{tabular}{cccccc}
\hline \multirow{2}{*}{ Temperature $\left({ }^{\circ} \mathrm{C}\right)$} & \multicolumn{5}{c}{ Time of storage (Days) } \\
\cline { 2 - 6 } & 0 & 30 & 60 & 90 & 120 \\
\hline 21 & $0.129 \mathrm{aA}$ & $0.144 \mathrm{aB}$ & $0.153 \mathrm{aC}$ & $0.156 \mathrm{aC}$ & $0.166 \mathrm{aD}$ \\
6 & $0.129 \mathrm{aA}$ & $0.137 \mathrm{bB}$ & $0.142 \mathrm{bC}$ & $0.143 \mathrm{bC}$ & $0.154 \mathrm{bD}$ \\
-12 & $0.129 \mathrm{aA}$ & $0.130 \mathrm{cA}$ & $0.129 \mathrm{cA}$ & $0.138 \mathrm{cB}$ & $0.141 \mathrm{cB}$
\end{tabular}

Different lower case letters in columns or different capital letters in lines indicate statistical difference by SNK test $(\mathrm{P}<0.05)$

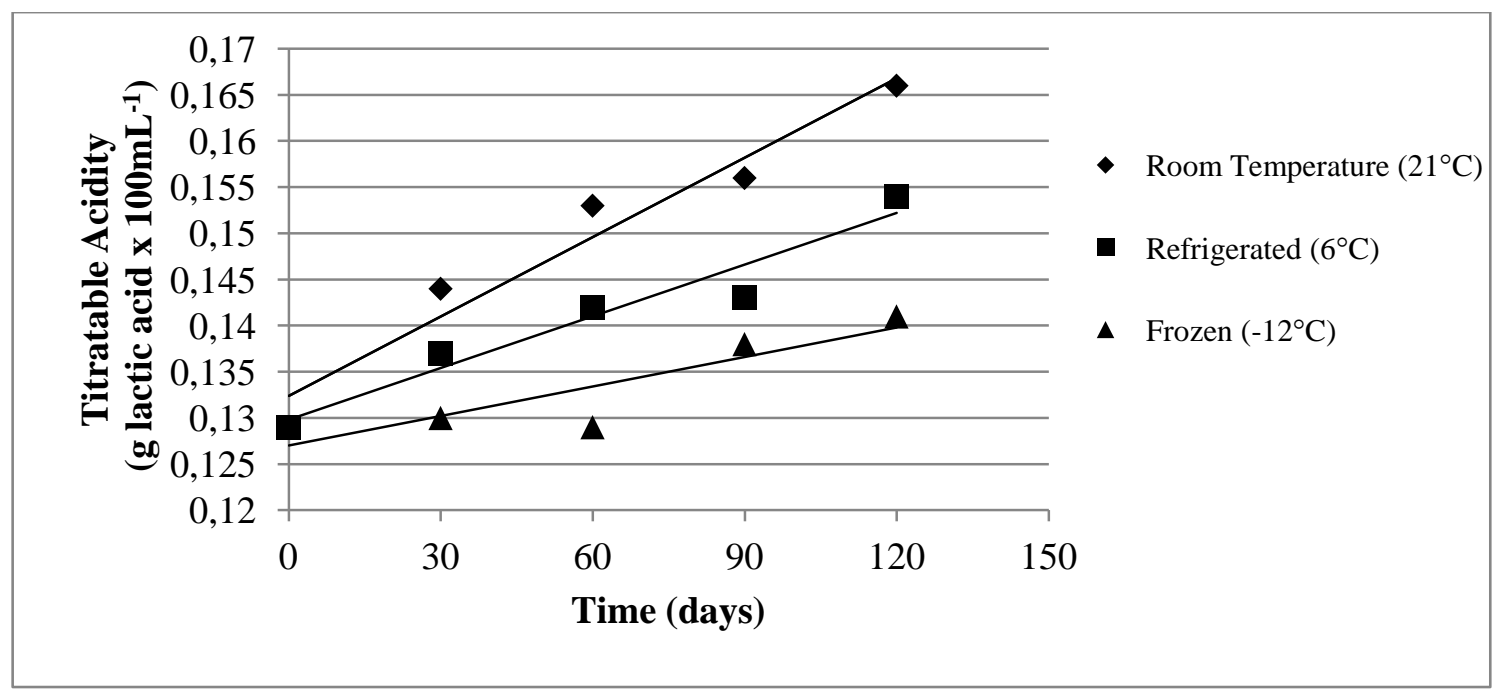

Figure 2. Effect of UHT milk storage time $\left(0,30,60,90\right.$, and 120 days) and temperature $\left(21^{\circ} \mathrm{C}, 6^{\circ} \mathrm{C}\right.$, and $-12^{\circ} \mathrm{C}$ ) on the titratable acidity (expressed as g lactic acid $\times 100 \mathrm{~mL}^{-1}$ ).

The regression curves and determination coefficients regarding Figure 2 are shown below:

- Room temperature $\left(21^{\circ} \mathrm{C}\right) \mathrm{y}=0.028167 \mathrm{t}+0.1326 \mathrm{R}^{2}=0.9549$

- Refrigerated $\left(6^{\circ} \mathrm{C}\right) \mathrm{y}=0.018278 \mathrm{t}+0.1303 \mathrm{R}^{2}=0.9438$

- Frozen $\left(-12^{\circ} \mathrm{C}\right) \mathrm{y}=0.010667 \mathrm{t}+0.1273 \mathrm{R}^{2}=0.7982$ 
Change in titratable acidity was significant after 30 days of storage, with higher acidity in milk stored at $21^{\circ} \mathrm{C}$, followed by milk stored at $6^{\circ} \mathrm{C}$ and $-12^{\circ} \mathrm{C}$. Low correlation $(29.6 \%)$ was found between titratable acidity and mesophilic microbial. However, correlation between CMP levels and titratable acidity was high $(69 \%)$ still indicating freezing as the best method to preserve UHT milk samples for CMP index analysis by HPLC.

According to the Brazilian legal requirements for UHT milk, titratable acidity, expressed as lactic acid, must range from $0.14 \%$ to $0.18 \%$ (Brazil, 1997). Of the 90 samples evaluated in the current experiment, 36 (40\%) were below the minimum acidity. From these samples, seven $(7.8 \%)$ were stored at $21^{\circ} \mathrm{C}, 11(12.2 \%)$ at $6^{\circ} \mathrm{C}$, and $18(20 \%)$ were frozen $\left(-12^{\circ} \mathrm{C}\right)$.
The UHT method exerts a very severe effect at the time of heat treatment, requiring a raw material of greater thermal stability to avoid flocculation in the equipment, which may cause inefficient heat exchange and more frequent interruptions for cleaning (Machado, 2010).

The analysis showed $\mathrm{pH}$ values in the $\mathrm{pH}$ range considered normal variations between 6.6 and 6.8 (Brito et al., 2007). There was no significant correlation index of CMP with $\mathrm{pH}$.

Among the samples stored at $21^{\circ} \mathrm{C}$, only four were found to be in agreement with the legal requirements for CMP index, which establishes a maximum level of $30 \mathrm{mg} \mathrm{L}^{-1}$ of CMP in milk destined to direct consumption (Brazil, 2006) (Table 4). This temperature treatment simulates a retailing condition. Non conformed samples had CMP levels ranging from 1.3 to 15.4 times above the allowed limit.

Table 4. CMP index (mg L-1) of UHT milk samples after storage at $21^{\circ} \mathrm{C}$ during 120 days $(\mathrm{n}=6)$

\begin{tabular}{cccccc}
\multirow{2}{*}{ Batches } & \multicolumn{5}{c}{ Time (Days) } \\
\cline { 2 - 6 } & 0 & 30 & 60 & 90 & 120 \\
\hline 1 & 26.17 & 148.57 & 337.42 & 461.08 & 461.28 \\
2 & 16.55 & 48.17 & 106.13 & 139.67 & 165.66 \\
3 & 39.08 & 100.05 & 173.19 & 230.11 & 266.75 \\
4 & 26.31 & 135.73 & 296.62 & 414.67 & 450.58 \\
5 & 23.24 & 50.38 & 84.08 & 107.42 & 128.01 \\
6 & 49.07 & 104.45 & 164.06 & 209.93 & 247.05 \\
\hline
\end{tabular}

These results indicate that recently produced UHT will present increasing proteolysis during its storage, with potential findings of nonconformed samples in the retail UHT milk, even when the original milk was normal.

Hence, fraudulent addition of cheese whey to the UHT milk can only be correctly detected soon after packaging.

The levels of CMP should not be used as the sole criterion for fraud indicator and should also consider the enumeration of psychrotrophic microorganisms present in raw milk (Oliveira et al., 2009).

Given the relationship that the CMP Index has with contamination from psychrotrophic raw milk this test has potential application in basis of criterion for guidance of public and industry policies for planning and actions to improve the quality of milk (operational hygiene, hygiene in milking collection, transportation and reception) in order to reduce at least the initial potential contamination with psychrotrophic proteolytic bacteria. In addition, the storage at temperatures below $7^{\circ} \mathrm{C}$ could contain its development (Oliveira et al., 2009).

Duplicate analyses resulted in low coefficient of variation for the CMP levels in all the experimental conditions (Table 5), confirming the high precision of this method. The average coefficient of variation, considering all treatments, was $1.88 \%$ (Table 5). 
Table 5. Coefficient of variation for CMP levels in UHT milk kept at 21,6 , and $-12^{\circ} \mathrm{C}$ and analyzed by HPLC

\begin{tabular}{cc}
\hline Temperature & $\begin{array}{c}\text { Coefficient of variation } \\
(\%)\end{array}$ \\
\hline $21^{\circ} \mathrm{C}$ & 1.67 \\
$6^{\circ} \mathrm{C}$ & 2.13 \\
$-12^{\circ} \mathrm{C}$ & 1.85 \\
\hline Average & 1.88 \\
\hline
\end{tabular}

These findings were according to WolfshoonPombo (1984), who reported a maximum coefficient of variation of $2 \%$, regardless of the CMP level.

The CMP index determination by HPLC addition is very precise, and is recommended internationally, but it is relatively expensive and requires trained personnel. As an alternative to the routine for detecting fraudulent addition of whey to milk, the spectrophotometric ninhydrin acid may be used due to its excellent correlation to the official method $(\mathrm{r}=0.981)$ (Fukuda et al. 2004), as well as by ELISA (Dupont et al., 2007).

\section{CONCLUSION}

There was a progressive increase of the UHT milk CMP index, measured by HPLC, under different temperatures and storage times, indicating the possibility of non-conformed samples in UHT milk analyzed in the market, even with original non adulterated milk. The detection of fraudulent addition of cheese whey to the UHT milk by HPLC determination of CMP levels must be done immediately after production, and not in samples collected in the retail market. When immediate analysis is not possible, UHT milk samples must be frozen and kept under this condition until the moment of analysis. HPLC determination of CMP is precise regardless of CMP concentration in the samples.

\section{ACKNOWLEDGMENT}

This work was supported by Laboratório de Análise da Qualidade do Leite - UFMG (Belo Horizonte, Brazil) and Fapemig (Minas Gerais, Brazil)

\section{REFERENCES}

BRASIL. Ministério da Agricultura Pecuária e Abastecimento. Portaria $\mathrm{n}^{\circ}$ 146, de 7 de março de 1996. Aprova os Regulamentos Técnicos de Identidade e Qualidade dos Produtos Lácteos. DOU. Brasília, DF, 11 de março de 1996.

BRASIL. Ministério da Agricultura Pecuária e Abastecimento. Portaria n.370, de 4 de setembro de 1997. Oficializa o Regulamento Técnico de Identidade e Qualidade do leite UAT. DOU. Brasília, DF, 8 de setembro de 1997.

BRASIL. Ministério da Agricultura, Pecuária e Abastecimento. Instrução Normativa $n^{\circ} 62$ de 26 de agosto de 2003. Oficializa os métodos analíticos para análises microbiológicas para controle de produtos de origem animal e água. DOU. Brasília, DF, 18 de setembro de 2003.

BRASIL. Ministério da Agricultura, Pecuária e do Abastecimento. Instrução Normativa $n^{\circ} 68$, de 12 de dezembro de 2006. Oficializa os métodos analíticos físico-químicos, para controle de leite e produtos lácteos. DOU. Brasília, DF, 14 de dezembro de 2006.

BRASIL. Ministério da Agricultura, Pecuária e do Abastecimento. Instrução Normativa $n^{\circ} 7$, de 2 de março de 2010. Oficializa a determinação de CMP em leite, por HPLC, eletroforese capilar e espectrometria de massas em leite, em apresentações integrais, semi-desnatadas $e$ desnatadas, tratados por processos de UHT ou pasteurização. DOU. Brasília, DF, 2 de março de 2010.

BRITO, M.A.; BRITO, J.R.; ARCURI, E. et al. $p H$ do leite. Agência de informação EMBRAPA. 2005. Disponível em: <http://www.agencia.cnptia.embrapa.br/Agencia 8/AG01/arvore/AG01_193_21720039246.html>. Acessado em: 21 out. 2010.

CROMIE, S. Psychrotrophs and their enzyme residues in cheese milk. Aust. J. Dairy Tech., v.47, p.96-100, 1992.

DUPONT, D.; LUGAND, D.; ROLETREPECAUD, O. et al. ELISA to detect proteolysis of ultrahigh-temperature milk upon storage. J. Agric. Food Chem., v.55, p.68576862, 2007.

FERREIRA, D.F. SISVAR: um programa para análises e ensino de estatística. Rev. Symposium, v.6, p.36-41, 2008. 
FOX, P.F. Indigenous enzymes in milk. In: SWEENEY, P.L.H.; FOX, P.F. Advanced Dairy Chemistry: Proteins, cap.2, 1. ed. London: BlakienAcademic e Professional, 1992. p.310320.

FRIEDRICH, M.T.; FRANKEN, R.B.C.; AZEVEDO, M.S. et al. Avaliação da estabilidade do leite in natura e UHT quanto ao índice de CMP. Rev. Cienc. Ex. Aplic. Tec. UPF, v.2, p.21-27, 2010.

FUKUDA, S.P. Estudo da correlação entre o método da ninidrina ácida e a cromatografia liquida de alta eficiência para a dosagem de glicomacropeptídeos e caseinomacroptídeo em leite. 2003. 137f. Tese (Tecnologia de Alimentos) - Universidade Estadual de Campinas, Campinas.

FUKUDA, S.P.; ROIGB, S.M.; PRATA, L.F. Correlation between acidic ninhydrin and HPLC methods to evaluate fraudulent addition of whey in Milk. Lait, v.84, p.501-512, 2004.

LASMAR, M.M.; LEITE, M.O.; FONSECA, L.M. et al. Detection of cheese whey in raw milk preserved with bronopol through high performance liquid chromatography. Arq. Bras. Med. Vet. Zootec., v.63, p.1553-1558, 2011.
MACHADO, S.C. Fatores que afetam a estabilidade do leite bovino. 2010. 189f. Tese (Pós-graduação em Zootecnia) - Universidade Federal do Rio Grande do Sul, Porto Alegre.

MAGALHÃES, M.A. Determinação de fraude de leite com soro de leite pela análise de CMP e pseudo-CMP por CLAE em fase reversa com detecção por espectometria de massa. 2008. 57f. Dissertação (Tecnologia de Alimentos) Universidade Federal de Viçosa, Viçosa.

OLIVEIRA, G.B.; GATTI, M.D.S.; VALADÃO, R.C. et al. Detecção da adição fraudulenta de soro de queijo em leite: interferência da atividade de proteases bacterianas. Rev. Inst. Lat. Cândido Tostes, v.64, p.56-65, 2009.

SISTEMA para Análises Estatísticas-SAEG, Versão 9.1: Fundação Arthur Bernardes - UFV Viçosa, 2007.

SAMPAIO, I.B.M. Estatística aplicada à experimentação animal. 3.ed. Belo Horizonte: UFMG, 2007.

WOLFSCHOON-POMBO, A.F. Adição de soro ao leite em pó - métodos de detecção. Rev. Inst. Lat. Cândido Tostes, v.39, p.3-10, 1984. 